\title{
What Deepest Remains: How Photojournalistic Mutualism Between Robert Capa and Elmer W. Lower Shaped Modern Concepts of World War II
}

\author{
Steven Holiday \\ holiday@apr.ua.edu \\ Dale L. Cressman \\ Brigham Young University, cressman@byu.edu
}

Follow this and additional works at: https://scholarsarchive.byu.edu/facpub

\section{Original Publication Citation}

Holiday, H. and Cressman, D. "What Deepest Remains: How Photojournalistic Mutualism Between Robert Capa and Elmer W. Lower Shaped Modern Concepts of World War II." American Journalism Vol 33 (no. 4) Fall 2016 Routledge http://dx.doi.org/10.1080/

08821127.2016 .1241644

\section{BYU ScholarsArchive Citation}

Holiday, Steven and Cressman, Dale L., "What Deepest Remains: How Photojournalistic Mutualism Between Robert Capa and Elmer W. Lower Shaped Modern Concepts of World War II" (2016). Faculty Publications. 4485.

https://scholarsarchive.byu.edu/facpub/4485

This Peer-Reviewed Article is brought to you for free and open access by BYU ScholarsArchive. It has been accepted for inclusion in Faculty Publications by an authorized administrator of BYU ScholarsArchive. For more information, please contact ellen_amatangelo@byu.edu. 


\title{
"What Deepest Remains": How Photojournalistic Mutualism between Robert Capa and Elmer W. Lower Shaped Modern Concepts of World War II
}

\author{
Accepted Manuscript for American Journalism Vol 33 (no. 4) Fall 2016 \\ Routledge http://dx.doi.org/10.1080/08821127.2016.1241644 \\ (C) 2016 American Journalism Historians Association
}

\section{STEVEN HOLIDAY AND DALE L. CRESSMAN}

Steven Holiday is a doctoral student in the College of Media and Communication at Texas Tech University, Box 43802, Lubbock, TX 79410, steven.holiday@ttu.edu. Dale Cressman is an associate professor in the School of Communication at Brigham Young University, 360 BRMB, Provo, UT 84602, cressman@byu.edu

Abstract: As American combat photographers documented the horrors and heroism of every major front of World War II, photo editors worked behind the scenes to bring their images to publication. Matching photographers with assignments and selecting images that best told the story - all while navigating censorship, publication expectations, and intercultural societal norms - the photo editor was indispensable to the combat photographer. The partnership of Robert Capa and Elmer W. Lower exemplified such a mutualistic relationship. Whether serendipitous, as it was early in the war when Lower provided assistance in exchange for Capa's photos, or calculated, as it was later in the war when both were employed by Life magazine, their experience exemplifies the mutually beneficial relationship of war photographers and their editors.

\section{Of hard-fought engagements or sieges tremendous what deepest remains? ${ }^{1}$}

Walter Lippmann remarked that most of us are too distant from the actual action of war to be able to learn about it firsthand. ${ }^{2}$ His philosophy, perhaps intended to imply geographic distance, could just as easily apply to the distance of time. In either case, war becomes real because the media bring it into people's living rooms through words and pictures. For scholar Susan Moeller, it is the pictures, and more specifically photography, that is "the medium by which civilians have visualized war."3 This may be because images "capture the essence of an issue or event

\footnotetext{
1 Walt Whitman, “The Wound-dresser," in The Complete Poems, ed. FrancisMurphy (London: Penguin, 2004).

2 Walter Lippmann, Public Opinion (New York: McMillan, 1922). See also Maxwell McCombs, Lucig Danielian, and Wayne Wanta, "Issues in the News and the Public Agenda: The Agenda-setting Tradition," in Public Opinion and the Communication of Consent, ed. Theodore L. Glasser and Charles T. Salmon (New York: Guilford Press, 1995, 281-300.

3 Susan D. Moeller, Shooting War: Photography and the American Experience of Combat (New York: Basic Books, 1989), xii. See also Jorge Lewinski, The Camera at War: A History of War Photography from 1848 to the Present Day (New York: Simon and Schuster, 1978), 9, who argued that photography "has made its mark on how we see and think about war in a way in which the first exponents in the nineteenth century could never have dreamed possible."
} 
graphically" by using the same rhetorical tools of metaphors, depictions, and symbols as words but tend to be more powerful than words at persuading and informing opinion since images are less intrusive and viewers read them as proof that they are witnessing truth. ${ }^{4}$

World War II was the first war that made combat on the front lines readily accessible in a timely fashion to the "armchair participant." 5 While it is true that photography has documented wars as early as the Crimean War, the photographic medium did not become useful for capturing action until developments including camera size and shutter speed were made in the twentieth century. ${ }^{6}$ Logistical advancements such as the radiophoto process and transcontinental airplanes brought the visceral images into the home as never before, and the resulting images have transcended time to become our modern conceptualization of that war. ${ }^{7}$

The process that brought the warfront to the home front required the involvement of a number of different people, but at its very foundational level, it required the mutualistic partnership of the photojournalist who waded into action and wielded the new device that made the war "journalistic, emotive, and episodic" and the editor who managed the assignments, chose the most representative photos, often wrote the captions, and handled the logistics of transmitting the images. 8

Today, there is a strong culture of photographers who recognize how dependent their work is on photo editors. As Kim and Jarecke point out, "Often it's an editor's voice that photographers hear in the back of their mind, urging them to strive harder for the defining image." 9 But during World War II, while the photojournalism profession was being redefined by technology and logistical advancements, this relationship was still in its infancy. Nevertheless, the work that came from these relationships was responsible for the indelible images we have of World War II.

This is not entirely surprising. After all, there is a healthy body of scholarship on interorganizational networks that are formed by alliances, and the research suggests that these types

${ }^{4}$ Lulu Rodriguez and Daniela Dimitrova, "Levels of Visual Framing," Journal of Visual Literacy 30, no. 1 (2011): 48-65, 51; Paul Messaris and Linus Abraham, "The Role of Images in Framing News Stories," in Framing Public Life: Perspective on Media and Our Understanding of the Social World, ed. Stephen D. Reese, Oscar H. Gandy Jr., and August E. Grant (Mahwah, NJ: Erlbaum, 2003), 215-226; Cori Dauber, "Image as Argument: The Impact of Mogadishu on US Military Intervention," Armed Forces \& Society 27, no. 2 (2001): 205-229.

${ }^{5}$ Moeller, Shooting War, 3.

${ }^{6}$ Lewinsky, The Camera at War, 37-43; Kevin G. Barnhurst and John Nerone, The Form of News: A History (New York: Guilford Press, 2001); Moeller, Shooting War, 195.

${ }^{7}$ Moeller, Shooting War, 181, 187.

${ }^{8}$ Barnhurst and Nerone, The Form of News, 173.

9 Yunghi Kim and Kenneth Jarecke, "Photo Editors Who Made a Difference," New York Times, August 20, 2013. See also "Editing Pictures, Influencing Photographers," New York Times, August 21, 2013. 
of relationships have a positive effect on innovation and performance. ${ }^{10}$ Matching theory states that alliances form when two organizations, entities, or individuals have goals that need to be met, recognize that each other possesses the resources to meet those needs, and identify internal qualities that would benefit the other party. If these criteria are met in both parties, a mutually beneficial match is created, and an alliance forms. ${ }^{11}$ While goals and resources motivate this model, there is a certain amount of serendipity involved in the process as well. ${ }^{12}$

There were many photo editors and photojournalists whose work exemplified World War II, but to illustrate their collective effect on modern conceptualizations of World War II, this study will highlight one editor-Elmer W. Lower - and one photojournalist-Robert Capa - and explore their alliance to examine how it led to the type of innovation and enhanced performance that ultimately exemplified World War II for all the generations that followed. In addition to viewing this relationship through the lens of match-ing theory and alliance formation, this study will further contribute to media history scholarship by examining a role for Lower that has not previously been provided in published literature. ${ }^{13}$

\section{The Players}

Robert Capa was the legendary photographer of five wars who was responsible for many iconic images that modern society associates with World War II. ${ }^{14}$ Elmer Lower was the pioneering executive of $\mathrm{CBS}, \mathrm{NBC}$, and $\mathrm{ABC}$ who helped make television a respectable medium for news and, ultimately, led ABC News from the time of the assassination of John F. Kennedy to the resignation of Richard Nixon. ${ }^{15}$ Capa and Lower were brought together by a series of events, between 1943 and 1945, while Capa was photographing World War II for Collier's and Life magazines, and Lower was a photo editor for the Office of War Information (OWI) and Life.

10 See Ranjay Gulati, "Social Structure and Alliance Formation Patterns: A Longitudinal Analysis," Administrative Science Quarterly 40, no. 4 (1995): 619-652; Ha Hoang and Frank T. Rothaermel, "The Effect of General and Partner-specific Alliance Experience on Joint R\&D Project Performance," Academy of Management Journal 48, no. 2 (2005): 332-345; Bharat N. Anand and Tarun Khanna, "Do Firms Learn to Create Value? The Case of Alliances," Strategic Management Journal 21, no. 3 (2000): 295-315.

11 Hitoshi Mitsuhashi and Henrich R. Greve, "A Matching Theory of Alliance Formation and Organizational Success: Complementarity and Compatibility," Academy of Management Journal 52, no. 5 (2009): 975-995.

12 Martin Kilduff and Wenpin Tsai, Social Networks and Organizations (Thousand Oaks, CA: Sage, 2003).

13 Although Lower's role as a television news executive has been previously documented (see Dale Cressman, "Fighting for Access: ABC's 1965-66 Feud with NASA," American Journalism 24, no. 3 (2007): 133-151), the early part of his career documented here has not been explored.

14 Ian Nathan, “Apocalypse Then,” Empire Magazine, October 1998.

15 Dale Cressman, “A Biographical Study of Television News Pioneer Elmer W. Lower" (unpublished doctoral dissertation, University of Utah, 2003). 
Although Lower sometimes thought Capa could be "absolutely undependable and somewhat of a pain in the keester [sic]," the photo editor grew to regard Capa as a gifted photographer who had a "good eye for subject and composition" and as a "military genius." For his part, Capa saw Lower as a "wily" editor with the proficiency to make sure Capa was in on the important campaigns of World War II. Nevertheless, he recognized that some felt Lower had a certain "inability to get along with superiors and fellow employees." 16 Clearly, the two respected each other as professionals. When it comes to recognizing the value and mutual benefit in a relationship, the two appeared to agree as well. According to Lower, Capa had "a knack of being where the big action is taking place." 17 This was no small compliment considering the risks that were being taken where the action was. For a photo editor and wartime propagandist such as Lower, there was nothing more fulfilling or important than having impactful action images from the front lines of a war to distribute to newspapers throughout the world.

Reciprocally, Capa recognized that "When you shoot, nearly every picture is the same to you, and the prize picture is born in the imagination of editors." 18 Clearly, Lower and Capa knew they needed each other, and they recognized that they could benefit each other as well. The following account of their interactions between 1943 and 1945-some strategic and intentional, others serendipitous - appropriately exemplifies matching theory and alliance formation and demonstrates how the modern concept of that war is, at least in part, attributable to relationships such as theirs.

\section{The Intertwined Lives of Lower and Capa}

By the time World War II began, Robert Capa had already amassed a reputation for his photographs of the Spanish Civil War. "The Falling Soldier" solidified Capa as "the American

16 For "good eye for subject," see Richard Whelan, interview of Elmer Lower, June 14, 1982, Robert Capa and Cornel Capa Collection, International Center of Photography (ICP), New York, NY, 3; for "military genius," see Elmer Lower to Gilberta Lower, January 1, 1945, unpublished Lower family archive. For "absolutely undependable," see Elmer Lower to Gilberta Lower, March 28, 1945, Lower family archive; even Capa's good friend George Rodger admitted that Capa was "a strange mixture of kind-heartedness and extreme egotism"; see Carole Naggar, George Rodger: An Adventure in Photography, 1908-1995 (Syracuse, NY: Syracuse University Press, 2003), 117. For "wily," see Robert Capa, Slightly out of Focus (New York: Henry Holt, 1947), 22. For comment of Lower's proficiency, see Richard Whelan, Robert Capa: A Biography (New York: Knopf, 1985), 233. Photo editor, and lifelong friend of Capa, John G. Morris even called Lower "quite capable"; see John G. Morris, Get the Picture: A Personal History of Photojournalism (Chicago: University of Chicago Press, 2002), 92. For "inability to get along," see Federal Bureau of Investigation, "Cleveland Field Report," April 14, 1942, file no. 77HQ-22924, Washington, DC.

${ }^{17}$ For "a knack of being," see Elmer Lower to Gilberta Lower, January 1, 1945, Lower family archive.

18 "Bob Capa Tells of Photographic Experiences Abroad," Hi! Jinx, October 20, 1947, radio interview, http://www.icp.org/robert-capa-100. 
photographer so daring, so determined to get as close as possible to the intensity of war."19 Similarly, by the start of World War II, Lower had seen the world as a reporter covering the 1938 Munich talks between Adolf Hitler and the leaders of Britain and France for the Newspaper Enterprise Association, and as a photo editor in Chicago and New York with the Associated Press. ${ }^{20}$ When the United States joined the war, following the attack on Pearl Harbor in December 1941, both Capa and Lower were ready to contribute their particular skills in the Allied efforts.

Capa set off for World War II in the spring of 1942, on assignment from Collier's, aboard a merchant ship convoy headed for London. Lower's journey, as a photo editor for the OWI, began aboard a Norwegian freighter destined for the Belgian Congo. After equally nerve-wracking journeys that required both ships to "run and dodge" Nazi submarines, both men coincidentally disembarked in mid-May. ${ }^{21}$ Lower's work began in Cairo where he set up radiophoto networks, got acquainted with other photo editors, and distributed news photos to newspapers and government installations throughout Africa, Palestine, India, and the USSR as well as London and New York. Lower was successful in his work and was even able to use the development, captioning, and presentation skills he had developed as a photo editor. Lower's work during this time extended to the production and distribution of billboards, posters, and pamphlets. He felt his labors were effective. ${ }^{22}$

From June 1942 to May 1943, Lower covered the broader war efforts as well as the Allied forces' efforts in North Africa that secured their first major victory against Hitler. ${ }^{23}$ It was during

19 See Alex Kershaw, Blood and Champagne: The Life and Times of Robert Capa (New York: Thomas Dunne Books, 2003), 38-47, for an analysis of the intense debate surrounding the image of "The Falling Soldier," a photograph of an Alcoy militiaman in the Spanish Civil War taken at the moment he was shot to death. Even though he was called an "American" photographer (see Kershaw, Blood and Champagne, 47), in reality, Capa was born in 1913 Budapest, Hungary, and was named Andre Friedmann. He "became" Robert Capa in 1936, hoping an American name might make his photography more marketable. See "Bob Capa Tells," Hi! Jinx, October 20, 1947.

${ }^{20}$ Lower's involvement in the Munich talks are chronicled in Dale Cressman, Elmer W. Lower Oral History (2000), 47-48, Series 19, C:0/46/60 (A07-115), 1 vol., 725, 1, 3 Small Holdings Box 1, University of Missouri Archives. His work as a photo editor is documented in Elmer Lower to Frank L. Martin, January 2, 1940 (Missouri School of Journalism), unpublished Lower family archive; Cressman, Elmer W. Lower Oral History, 50.

21 For "run and dodge," see Illustrated, June 13, 1942; German U-boats claimed a total of 343 Allied merchant ships between April and June 1942; see John Kegan, ed., Harper Collins Atlas of the Second World War (Ann Arbor, MI: Borders Press, 1999), 88-89. For dates of passage, see Kershaw, Blood and Champagne, 92; Cressman, "A Biographical Study," 112.

22 See Cressman, "A Biographical Study," 120, for distribution outlets for Lower's work. Lower recognized how the skills he had obtained as an editor could contribute to his work and recorded it in Elmer Lower, diary, August 26, 1942; he detailed the platforms where his work had effect in Elmer Lower, fax to James Linen, Special Reports Division, Office of War Information, October 24, 1942, original copy in unpublished Lower family archive.

${ }^{23}$ Kershaw, Blood and Champagne, 99. 
this time that Lower first became acquainted with the photojournalists who were covering the war. In exchange for darkroom services, photographers, such as George "Slim" Aarons, gave Lower special, advanced access to photos they had taken from the desert theater. ${ }^{24}$ Capa, on the other hand, spent the fall and subsequent winter of 1942 in England awaiting credentials to cover military operations outside of Britain. While he waited, he did a few routine stories for Collier's and also got to know fellow photographer Aarons.

Capa's biggest lesson learned from his time in England came in September 1942, as he photographed the mangled casualties and victims of a particularly harrowing bombing run as they were lifted from battered Flying Fortresses. When one B-17 pilot emerged, he angrily confronted Capa, causing him to feel like an opportunistic coward and voyeur. Capa wrote that he "hated [himself] and [his] profession" for taking photographs better suited to "undertakers," and he decided then and there that the only way he would be able to document the war and earn the respect of the soldiers would be to join the missions or, as he called it, the "procession." 25

When Capa's credentials finally arrived, he was able to join the efforts in North Africa and document the final stages of the war in the desert theater. He followed the action to Tunisia, where his "front-line" pictures of the battle for El Guetar were, as one biographer wrote, "taken at considerable risk." His next mission was aboard a B-17 bomber, the same Flying Fortresses that had convinced him to join the "procession," where he spent multiple days photographing bombing raids of harbors and ports throughout the Tyrrhenian and Mediterranean Seas. When Capa returned to the press camps each evening, the correspondents typed their stories, and he shipped his pictures. ${ }^{26}$

Capa's photos were of considerable benefit to Lower and the OWI. As a result of Capa's chutzpah, Lower processed impressive aerial photos containing such detail they looked as though they were taken from five hundred feet above, although Lower knew they were taken from much higher altitude. The photographs ended up on the front pages of newspapers in the Middle East, as well as in the New York Times - even on billboards in downtown Cairo-despite logistical challenges such large images posed for Lower and his staff. ${ }^{27}$ As a result, Capa's work gained even wider exposure than Collier's could provide.

${ }_{24}$ Elmer Lower, diary, January 7, 1943, Lower family archive; Elmer Lower, diary, January 26, 1943, Lower family archive. Lower called Aarons "quite a character" and "the most uninhibited fellow [he'd] ever met." The two established an amicable relationship where they exchanged photos for darkroom services.

25 Capa, Slightly Out of Focus, 25.

26 Capa's coverage of the battle for El Guetar was printed in Collier's, June 19, 1943. For work on the bombing raid missions, see Capa, Slightly out of Focus, 25, 48-50; Kershaw, Blood and Champagne,101102

27 Elmer Lower, diary, November 23, 1942. The OWI darkroom was not equipped to easily print fortyinch photos for the Cairo billboards. 
After securing North Africa in an ambitious campaign that spread from the Atlantic Ocean to the Suez Canal across one of the world's most inhospitable terrains, Allied forces shifted their regional focus toward Italy during the summer of 1943. After brief coinciding leaves - Capa returned to Time's England country estate retreat, "Time Out," while Lower returned home to New York - the two were ready to move to Italy, where they would, to mutual benefit, use their unique skills for visually capturing combat. ${ }^{28}$

\section{Italy}

Capa, who had been hired by Life after his contract with Collier's ended, got to Italy in September 1943 and became "the first photographer to record the liberation of the first major European city" on October 1 when he "accompanied the 82nd Airborne on their final push into Naples." 29 The sight that welcomed him was equal parts elation and heart-gripping pitybeautiful frescoes that adorned the walls of the ancient ruins of Pompeii were juxtaposed with graffitied walls in the new ruins of Naples. Bodies were strewn throughout the historic vias and piazzas, left behind by the indiscriminate killing and looting of retreating Germans. Capa later wrote that the sights he photographed in those first few days were "the greatest horrors of the war" and "[his] truest pictures of victory." 30

After Allied forces had secured the city, Lower arrived at the beginning of November to set up a radiophoto operation for the OWI. ${ }^{31} \mathrm{He}$ and his colleagues requisitioned a small commercial photo studio-lab and an apartment in which to put it. It was a few blocks from the harbor, considered to be "the safest area in Naples." 32 Lower "let all the war photographers develop their film in this studio," and, as a result, the shop and accompanying apartment became the unofficial headquarters for press photographers as they came and went from the front. ${ }^{33}$ Lower was

28 Cressman, Elmer W. Lower Oral History, 220; Kershaw, Blood and Champagne, 102-103.

29 Capa's move from Collier's to Life is chronicled in Capa, Slightly out of Focus,78. For "the first photographer to record" and "accompanied the 82nd," see Kershaw, Blood and Champagne, 108.

30 Capa wrote of the walls with graffiti in Slightly out of Focus, 103; the strewn corpses in the piazzas are reported in Illustrated, May 13, 1944, where he referred to this work as "the greatest horrors" before recalling these images as his "truest pictures"; Capa, Slightly out of Focus, 104.

31 Elmer Lower to Gilberta Lower, November 3, 1943; Cressman, Elmer W. Lower Oral History, 73.

32 Bill Mauldin, The Brass Ring (New York: W.W. Norton, 1971), 185-188. See also Cressman, Elmer W. Lower Oral History, 73; Elmer Lower to Dale Cressman, August 18, 2002; Elmer Lower to Bill Mauldin, 25 August 2002; Elmer Lower to Gilberta Lower, November 3, 1943.

33 Elmer Lower to Dale Cressman, August 18, 2002. 
reunited with Slim Aarons, and he was joined by Burgess Scott, G. Brown Roberts, Frank Adams, George Rodger, Don Whitehead, Will Lang, and Capa, among others. ${ }^{34}$

Capa and Rodger - who met each other in Naples as well and became fast friends - had been sending their rolls, captions, and directions to Life, in London, to edit and publish their stories. But after a series of power struggles and miscommunications with Life led to what they felt were misrepresentations of some of their work and complete disregard for other stories they had labored on and become emotionally invested in, the two decided to develop their film and edit their stories themselves in Naples and forward the prints to Life instead of sending the undeveloped negatives. ${ }^{35}$ Since the OWI was the only Allied operation allowed to develop photos in Naples at the time, all photo development went through Lower's studio, and, recognizing a mutually beneficial arrangement, he was happy to accommodate the photojournalists. ${ }^{36}$ This was the first time that Lower met Capa in person, and while Lower's facilities provided a valuable service to Capa, Capa's access and abilities provided Lower with the content he needed to continue chronicling the war effort. This mutualistic alliance would lay the foundation for a successful future relationship.

The apartment building also housed the staff of the 45th Infantry Division News, which published a weekly paper and delivered it to all the division's soldiers. Because the division news staff's own apartments did not have heat, many of the 45th's staff also became regulars in Lower's apartment - one of the few rooms with a potbellied stove and, consequently, warmthwhere they worked so their fingers would not get numb. ${ }^{37}$ Among the news staff was cartoonist Bill Mauldin, who worked late into the nights in Lower's apartment, long after everyone else had gone to bed, on his series Up Front with Mauldin, for which he would win the Pulitzer Prize in 1945. At odds with military brass, Mauldin undoubtedly benefited not only from a safe, warm environment but also from moral support and camaraderie. Lower admired Mauldin and his "wonderful cartoons," and Capa argued that at a time when pictures did a better job than words

\footnotetext{
34 Ibid.; Elmer Lower to Bill Mauldin, August 25, 2002; Cressman, Elmer W. Lower Oral History, 73; Naggar, George Rodger, 120; Elmer Lower to Gilberta Lower, July 20, 1945, where, upon the arrival of Aarons and his correspondent counterpart, Scott, in Naples, Lower exclaimed, "Everything can begin now."

35 Whelan, Robert Capa, 201; Naggar, George Rodger, 120; George Rodger to Cicely Rodger, December $25,1943$.

36 Elmer Lower to Gilberta Lower, November 13, 1943.

37 Elmer Lower to Dale Cressman, August 18, 2002; Cressman, Elmer W. Lower Oral History, 74.
} 
at capturing the awful truth of the war, it was Mauldin's Willie and Joe cartoons that represented the "fighting dogfaces of Italy." 38

Photographers and journalists huddled together in the heated living room of Lower's apartment to keep warm, work together, eat together, and become well acquainted with each other during the "cold and terrible" Italian winter that Mauldin insisted was worse than Valley Forge. 39 Their assignments included the Monte Pontano campaign that slowed the Allied advance to just ten miles in two months and was immortalized in Capa's photo story "It's a Tough War." The Battle of Monte Cassino would rage on for months at an eventual cost of fifty-five thousand Allied casualties and earn Mauldin his Purple Heart. Together, they experienced the local black market, a typhus epidemic, a lice outbreak, and the tyrannical Naples MPs. ${ }^{40}$ But each found refuge between assignments in the little apartment on Piazza Nuova Carita. ${ }^{41}$

For Christmas dinner in the weeks leading up to 1944, the men prepared a turkey, acquired canned food, and made the place feel like home as they shared the meal between the five to ten journalists and photographers who were there between assignments. ${ }^{42}$ Amid the chaos swirling all around them was a volcanic eruption-what Lower called "the magic red tongue of Mt. Vesuvius [illuminating] the heavens." It buried villages in molten lava and red cinders and covered the city of Naples in soot and smoke with "its greatest show in a hundred years." According to AP correspondent Ed Kennedy, Vesuvius "surpassed anything I saw in the war. As a destructive force it was more gripping, if only minutely as extensive." 43 In such circumstances, the men were determined to have a place to call home and a surrogate family with which to share it. In describing the relationships that were formed on the Italian front lines that winter, Lower

38 For "fighting dogfaces," see Capa, Slightly out of Focus,107; for "wonderful cartoons," see Elmer Lower to Bill Mauldin, August 25, 2002. Lower told his wife, Gilberta, multiple times that Mauldin was "quite a talented lad" and a "swell kid" (Elmer Lower to Gilberta Lower, December 5, 1943; see also Elmer Lower to Gilberta Lower, December 7, 1943; Elmer Lower to Gilberta Lower, December 15, 1943). Mauldin's irreverent, unrestrained commentaries during the war years earned him both the ire of commanding officers, including General George Patton, as well as the veneration of the common soldiers and Supreme Commander Dwight Eisenhower, who felt Mauldin's work had a positive influence on soldiers. Todd DePastino, Bill Mauldin: A Life up Front (New York: W.W. Norton, 2008).

${ }^{39}$ Fredrick C. Painton, “Up Front with Bill Mauldin,” Saturday Evening Post, March 17, 1945, 71.

40 For Monte Pontano, see Capa, Slightly Out of Focus,108, and“It's a Tough War," Life, January 31, 1944; for Monte Cassino, see Allen Axelrod, Real History of World War II: A New Look at the Past (New York: Sterling, 2008), and for events in the city of Naples that winter, see Mauldin, The Brass Ring, 185-201.

${ }^{41}$ Elmer Lower to Bill Mauldin, August 25, 2002, Lower family archive.

42 Cressman, Elmer W. Lower Oral History, 74-75; Elmer Lower to Gilberta Lower, December 26, 1943, Lower family archive.

43 For "Magic red tongue," see Elmer Lower to Gilberta Lower, November 3, 1943; for "its greatest show," see Capa, Slightly Out of Focus, 111; for "surpassed anything I saw," see Ed Kennedy and Julia Kennedy Cochran, Ed Kennedy's War: V-E Day, Censorship, \& the Associated Press (Baton Rouge: Louisiana State University Press, 2012), 122-123. 
wrote that many of the men confided in him personally, and journalist Ernie Pyle - who also happened to be in Naples that winter-wrote that "the ties that grow between men who live savagely together, relentlessly communing with Death, are ties of great strength." 44

In the end, Mauldin wrote, Naples was "spectacularly beautiful, even with all the damaged buildings and sunken ships cluttering the harbor"; Lower recalled, "It was a great place to be." Even Capa, who had declared, "Naples was no good," eventually admitted that "the town looked beautiful." 45 They had survived Naples together, and those iconic artists would go on to create work that represented the face and lasting impressions that historians, war veterans, and future audiences would have of the events of World War II. ${ }^{46}$

In the first weeks of 1944, the war progressed "up the spine of Italy," away from Naples, bringing the journalists with it. First, Capa, Aarons, Scott, Mauldin, Bert Brandt, and Don Whitehead joined thirty-six thousand troops on January 22, 1944, in the invasion of Anzio, an attempt by Allied forces to create an alternate route to Rome. ${ }^{47}$ While Capa was initially disappointed by the lack of military action, it was not long before "the whole beachhead was under shellfire" as the German bombers started unleashing their load in "the heaviest bombing yet endured by American forces in the Second World War." 48 From then on, despite jagged nerves and frayed tempers, Capa, Aarons, and the others felt it their duty to chronicle the war and tell the soldiers' story - "it made [the soldiers] feel that they were not forgotten, that the people at home were following their every move." 49 To do so, they documented the action on the most

${ }^{44}$ For Lower as confidant, see Elmer Lower to Gilberta Lower, February 2, 1944, Lower family archive; for Pyle in Naples, see James Tobin, Ernie Pyle's War: America's Eyewitness to World War II (New York: Free Press, 1997), 133; Mauldin, The Brass Ring, 208, 211; for "the ties that grow," see Ernie Pyle, Brave Men (New York: Henry Holt, 1944), 197.

45 For "spectacularly beautiful," see Mauldin, The Brass Ring,191; for "It was a great place," see Cressman, Elmer W. Lower Oral History, 74; for "Naples was no good" and "the town looked beautiful," see Capa, Slightly out of Focus, 106, 133.

46 Capa's work on D-Day influenced Steven Spielberg's World War II epic Saving Private Ryan. Mauldin's dogfaces inspired Charles Schultz's Veterans Day Peanuts strips for three decades, culminating in one last depiction of Willie and Joe by Mauldin in 1998 (see Charles Schultz, "Peanuts," November 11, 1998). And author Chaim Potok would be forever haunted, impressed, and inspired by George Rodger's images from Bergen-Belsen concentration camp. See Chaim Potok, In the Beginning (New York: Knopf, 1975), 377.

${ }^{47}$ Kershaw, Blood and Champagne, 111.

48 For Capa's disappointment, see Whelan, Robert Capa, 205. The initial successful surprise invasion of Anzio was so devoid of action that Capa openly displayed his disappointment in the lack of quality material to cover while he roamed the beach. He was so upset that when a German plane fired on the beach, he was the only person who did not dive for cover, instead opting to remain, stubborn and disdainful, seat on the hood of a Jeep. For the "whole beachhead," see Kennedy and Cochran, Ed Kennedy's War, 120; for "the heaviest bombing," see Kershaw, Blood and Champagne, 114.

49 For jagged nerves and frayed tempers, see Kershaw, Blood and Champagne, 115; for "it made [the soldiers]," see Kennedy and Cochran, Ed Kennedy's War,120. 
dangerous parts of the beach, where German bombs "sent fiery bits of fragments through the fragile, canvas structures" of the troops' tents. ${ }^{50}$

The photography these men captured kept Lower busy in Naples. The photo editor strived to ensure that the people at home were receiving the photojournalists' pictures of the effort, in his words, "faster than any other time in this war-and that, of course, means in history." The first action photos arrived on January 23 and included "plenty of good pictures." Lower worked quickly to personally get the photos processed through the darkroom and the censor so he could send them by radiophoto in time to be printed in the New York papers, specifically, as well as in other scheduled papers he oversaw. How the images were received and perceived back in New York was so important to Lower and his team that they were "holding [their] breath - hoping that they were good." 51 Clearly, Lower understood the power and importance of providing the home front with the photojournalists' timely images that captured the action well.

If it is any indication of the dangerous lengths to which the correspondents went to capture the action well in Anzio, Scott wrote that he "breathed easily and relaxed completely for the first time in seventeen days" once he was on a boat back to Naples and Anzio land was out of sight. Even Capa was "badly shaken" by his time there. As the operation became more intense, the AP ordered its personnel to leave, but feeling it "imperative that the AP be represented on Anzio while there was important news there," local AP staff not only disregarded the order, they sent in more correspondents, including Pyle.52 Capa, however, was ready to abandon the pictureless, storyless location for a more agreeable front. When his orders came, he delayed acting on them, but he ultimately accepted the transfer to London. ${ }^{53}$

\section{Preparing for D-Day}

London was the preeminent place for a correspondent, photographer, filmmaker, or editor to be in the spring of 1944. The air was ripe with the scent of anticipation and electrified by "invasion jitters." Although nobody knew the precise date, Lower remembered that everyone knew that the Al-lied invasion of France was on the horizon, and, in preparation, the OWI reassigned Lower to London in February to make preparations for the photo coverage of the campaign. Lower

50 Robert Vermillion, "UP Writer Tells of Nazi Bombing of US Hospitals," Paducah Sun-Democrat, March 30,1944, 18. See also Kershaw, Blood and Champagne, 114; Mauldin, The Brass Ring, 216; Whitehead, Beachhead Don, 108.

51 For "faster than any other time," "plenty of good pictures," and "holding [their] breath," see Elmer Lower to Gilberta Lower, January 23, 1944, Lower family archive.

52 For "breathed easily," see "Further Experiences of Sgt. Scott in Covering Anzio-Nettuno Landings for Yank," Paducah Sun-Democrat, March 16, 1944, 15; for "badly shaken," see Kershaw, Blood and Champagne,115; for "imperative that the AP be represented," see Kennedy and Cochran, Ed Kennedy's War, 120. See also Tobin, Ernie Pyle's War, 154; Don Whitehead to Lee G. Miller, October 26, 1945, Miller Papers, Ernie Pyle State Historic Site, Dana, IL.

53 Capa, Slightly Out of Focus, 115-116. 
immediately found his work to be "interesting and on a much larger scale" than it was in the Mediterranean. ${ }^{54}$

Among his tasks was to make arrangements with the Army Signal Corps and photo pools to obtain news photos on D-Day, so they could be quickly distributed worldwide by radio. He used the training landings be-ing conducted in Scotland to fine-tune the timing and logistics. He also continued his usual work of providing "white propaganda," or accurate information from a known source, to the British press. In his preparations, he began to realize that he would be very busy once D-Day arrived, and he warned his wife that his letters would be fewer and briefer as a result. 55

Nevertheless, he did find time to enjoy the pleasures of London. Spring-time in the city was a welcome change from his time in Egypt and Italy. The horse-chestnut blossoms were in bloom, and Lower had acquired a taste for dry sherry and trifle. ${ }^{56}$ Lower was not the only one drinking, though his habit would prove much more innocent and harmless than others. Pyle, who arrived in London in April, had taken to drinking himself to sleep to relieve the weight of fear, while Capa built a reputation for touring pubs and host-ing parties where he served cocktails and blackmarket booze to soothe his pre-invasion nerves. Aarons, Rodger, and Ernest Hemingway also arrived in London and found their way to the bars as they awaited D-Day. ${ }^{57}$

Fear or no fear, D-Day was coming, and no amount of alcohol could wash it away. By May 1944, the Allied preparations for the invasion were finished, and the forces were ready. Eisenhower personally told the war correspondents that they would be included in the campaign. "Our countries fight best when our people are best informed," he told a meeting of four hundred and fifty reporters on May 22. "You will be allowed to report every-thing possible, consistent, of course, with military security." 58 Additionally, the US Army called on Capa, Lower, and other

\footnotetext{
54 For "invasion jitters," see Whitehead, Beachhead Don, 115; for Lower's assessment of feelings of the pending invasion, see Cressman, Elmer W. Lower Oral History, 78; for "interesting," see Elmer Lower to Gilberta Lower, April 27, 1944, Lower family archive.

55 Elmer Lower to Gilberta Lower, May 15, 1944, Lower family archive.

56 For horse-chestnut blossoms, see Kershaw, Blood and Champagne, 117; for dry sherry and trifle, see Cressman, Elmer W. Lower Oral History, 77.

57 Pyle's experience and the exploits of Capa and others while in London are chronicled in Kershaw, Blood and Champagne, 117-119; and Tobin, Ernie Pyle's War, 156, 165.

58 Untitled speech, May 22, 1944, Records of the Public Relations Division, SHAEF, Record Group 331, National Archives and Records Administration, Washington, DC. Also covered in "450 Reporters Covering Invasion of Europe," US Air Services, July 1944.
} 
photojournalists to give a series of lectures to its own photographers to prepare them for work on the front. 59

Pyle's bedding was taken to a secret destination, by an Army PRO, during the last week of May, and Sam Brightman, a good friend of Lower's from his Missouri days, who was stationed with the Army outside of London, sent Lower a trunk of almost everything he had, since "he couldn't take much" with him. When the trunk arrived, Lower "knew it was getting close." Whitehead, who had also arrived in London from Italy in April, reported during the last days of preparation that "The day is drawing close when thousands of American youths. . will storm the beaches of Europe in the supreme test of the infantryman in World War II."60

Just days before the campaign commenced, the few dozen correspondents chosen to accompany the invasion - only four of whom were photographers - were called to a meeting at the Allied Forces Public Relations Office, where they were told to pack, provide details of their last will, and not travel away from their apartments for more than an hour at a time. ${ }^{61}$ They conducted their last-minute shopping, and the photographers for Life posed for a picture together in Grosvenor Square, just outside of Lower's office. ${ }^{62}$

When command started assembling the correspondents the week before the invasion, "almost everyone was taken by surprise," but there was no question what it was for, even though the Public Relations Division tried to make it nonchalant. ${ }^{63}$ Apparently, the only person caught completely by surprise was Capa, who received a personal wake-up visit from a public relations officer who told him he had to leave immediately, rather than having the sixty to ninety minutes given to the other correspondents to make final preparations and show up at an arranged meeting point. 64

59 Whelan, Robert Capa, 209; Elmer Lower to Gilberta Lower, May 6, 1944, Lower family archive. Life photographers alone spent over six thousand man-days on the fronts of World War II (see "Under Fire: Combat Coverage across Five Decades of War,” Life Special Anniversary Issue: 50 Years,1986, 127).

${ }^{60}$ For Pyle, see Tobin, Ernie Pyle's War, 165; for Sam Brightman, see Cressman, Elmer W. Lower Oral History, 78; for Whitehead, see Whitehead, Beachhead Don, 117.

${ }^{61}$ Capa, Slightly Out of Focus, 139-140; Kershaw, Blood and Champaign, 119.

62 Kershaw, Blood and Champaign, 120; Naggar, George Rodger, 124; Cressman, Elmer W. Lower Oral History, 76.

${ }^{63}$ Whitehead, Beachhead Don, 119. See also Kershaw, Blood and Champagne, 120; Tobin, Ernie Pyle's War, 166.

${ }^{64}$ Kershaw, Blood and Champaign,120; Tobin, Ernie Pyle's War, 166; Whitehead, Beachhead Don, 119.

13 
The extraction of the D-Day correspondents from London happened in a shroud of silence. There were no phone calls made, no notes written. ${ }^{65}$ Editors such as Morris and Lower certainly noticed when some of the most elite photographers, who had been providing them the iconic material they had been using for publication and distribution, seemingly vanished one morning only weeks after being selected to be included in the D-Day campaign. Even their letters home suggested that they sensed that the invasion was imminent from that very first day, but they still had no more idea of when the campaign was going to happen. ${ }^{66}$ For a time, photographers and editors were on their own.

\section{D-Day}

On the morning of June 6,1944, however, the whole world would be-come aware of the Allies' plans. It was a massive undertaking - the largest amphibious assault in the history of human warfare. It is estimated that "over a thousand warships and as many as4,126 landing vessels, with 1,000 other ships. . . [delivered] 175,000 men and 1,500 tanks, 3,000 guns and 5,000 assorted trucks, jeeps, etc., to the beaches of Normandy." 67 Nine correspondents assigned to the invasion were left in England, the result of logistical mistakes made by the Army's Public Relations Division. Those who did make it ashore on D-Day were faced with the frantic, dangerous business of war. One Signal Corps photographer lost a leg in the first hours. Others were faced with something so overwhelming that their journalistic skills were said to have eluded them. ${ }^{68} \mathrm{Of}$ the seven hundred thousand words the correspondents filed on the first day, the most honestly representative may have been those of Tom Treanor, in one of the first dispatches from Omaha Beach: "It was too much to describe." ${ }^{69}$ Even Whitehead, who had previously participated in the invasions of Sicily, Salerno, and Anzio was "nervous and scared like everyone else" when he accompanied the landing on Omaha Beach. His senses eventually became so overloaded that

65 Whitehead, Beachhead Don,119. Altogether, 558 correspondents, photographers, and filmmakers were extracted to Scotland under a meticulously planned extraction that was arranged to elude German notice. See Lewinsky, The Camera at War, 126.

66 Beginning with a letter on May 29, Lower's personal correspondences curiously began nonchalantly omitting mention of correspondent friends who had been ever present in all prior letters. And on June 3, he made the only reference that may be inferred as an awareness of what was happening, when he wrote, "I haven't seen near enough of Hal [Boyle] or Don [Whitehead]. I rather think they are away now" (Elmer Lower to Gilberta Lower, June 3, 1944, Lower family archive; see also Elmer Lower to Gilberta Lower, May 29, 1944, Lower family archive.

${ }^{67}$ Lewinsky, The Camera at War, 126.

68 The overwhelming nature of the event is reported in Phillip Knightley, The First Casualty: The War Correspondent as Hero and Myth-maker from the Crimea to Iraq (Baltimore: Johns Hopkins University Press, 2004), 332.

${ }^{69}$ For "it was too much," see Tom Treanor, Washington Post, June 8, 1944. Treanor, who had only recently joined the Los Angeles Times before the Normandy invasion, tried to explain the sheer magnitude of the assignment a few weeks later for Vogue (see Tom Treanor, "What Did You See, Tom?"” Vogue, October 1944) before he was killed outside of Paris (see Tobin, Ernie Pyle’s War,173). 
after the success of the initial push, he wrote his first story on the invasion and fell asleep in a foxhole, where Pyle found him when he came ashore the morning of June 7.70

Once again, this seemed to be a mission best suited to visual rhetoric and to the proficiencies of photographers, "a race apart" that was often called on to do things that failed other people. ${ }^{71}$ The select few who drew the assignment to capture the initial action on Normandy included Life photographers Capa and Bob Landry, Acme photographer Bert Brandt, and AP photographer Weston Haynes. For these photographers, "there were picture possibilities everywhere." 72 They started capturing the action from the decks of their boats and continued as they waded ashore, dodged the German artillery, and pushed past the hundreds of bodies that had fallen all around. ${ }^{73}$ They took pictures "as fast as [they] could change film," because it was "the only way to overcome the terror." The action was so quick and hectic that Landry lost his shoes. "I had it bad," Capa later recalled. "The empty camera trembled in my hands. It was a new kind of fear shaking my body from toe to hair, and twisting my face." 74

After they captured the action, the photographers fought their way back to the ships in the harbor with their prized images of war. Landry's film was lost when "all of the movie films and other films taken by army photographers were accidentally dropped in the Channel on the way back to England." Brandt kept his film in his possession across the Channel, and when he arrived in Weymouth, England, he was given a Jeep to drive to London. Capa personally escorted his film as far as Weymouth as well, where he was offered a plane to London, but opting to return tot he front as soon as possible, he sent his film by courier, changed clothes, and headed back to Normandy a few hours later. ${ }^{75}$

In London, Lower was praying for correspondent friends while he anxiously waited for the images to arrive. After extensive training and months of preparation, he was blessed with propitious timing when a scheduled exercise of the distribution of the radiophotos coincidentally coincided precisely with D-Day. ${ }^{76}$ Brandt's pictures came first, and the censor-approved images

\footnotetext{
70 Whitehead, Beachhead Don, xvii-xix; Tobin, Ernie Pyle's War, 173.

${ }^{71}$ Kennedy and Cochran, Ed Kennedy's War, 91.

72 Brandt, "I Cover the Battlefront," 84.

73 Ibid., 84-85; Kershaw, Blood and Champagne, 124.

74 For "as fast as," see Brandt, "I Cover the Battlefront," 85; for "the only way to overcome," see Kershaw, Blood and Champagne, 125; for Landry's shoes, see Simon Super, "Interview: John Morris on his Friend Robert Capa," FT Magazine, May 31, 2013, http://www.ft.com/cms/s/2/3d37a03e-c8be-11e2acc6-00144feab7de.html\#slide9 (accessed June 23, 2016); for "I had it bad," see Capa, Slightly out of Focus, 148 .
}

${ }^{75}$ For Landry's experience, see Kuper, "Interview: John Morris"; for Brandt's, see Brandt, "I Cover the Battlefront," 85; for Capa's, see Capa, Slightly Out of Focus,150-151.

${ }^{76}$ Elmer Lower to Gilberta Lower, June 11, 1944, Lower family archive. 
featured troops landing but inexplicably lacked the action shots he must have captured in the multiple rolls he took. 77

Capa's pictures arrived next. Editors were puzzled as to why there were only ten grainy and blurry images. ${ }^{78}$ As Brandt noted, "A combat photographer doesn't have much time to fool around with 'trick' shots." 79 Thus Morris initially attributed the blurring to a lab accident. When it published the photos, Life reported it was the "immense excitement" on the beach that resulted in blurred images. For his part, Capa admitted nervousness. Later it was learned that most of the images Capa captured were accidentally destroyed in the lab. ${ }^{80}$ In any event, Capa's images viscerally portrayed the frantic first moments of the invasion that he and every other soldier and correspondent experienced on the beaches of Normandy that day.

Haynes's photographs also arrived in London in the days following D-Day. Even though they did not have the fanfare or drama of Capa's, Brandt's, or Landry's images, Haynes's work excited Lower more than any of the others. Although Lower was simultaneously helping to distribute Capa's photos, Lower thought Haynes's work was "smashing." In a letter to his wife, Lower wrote, "Wes is doing a marvelous job. Thank God he is alive and carrying on so far." 81

The same frenetic energy that had propelled each of the photographers through the invasion gave Lower a surge of adrenaline as he prepared the photos for distribution to an eager pool of newspaper editors from around the world. He excitedly worked fourteen- to nineteen-hour days to prepare what he called "the best show so far on pictures." 82 The editors' radiophoto process became the photographers' saving grace in the days following D-Day and throughout the war, for it allowed their pictures to be "published in papers all over the United States" within four hours. ${ }^{83}$

77 Brandt, "I Cover the Battlefront," 84-85; Kershaw, Blood and Champagne,128.

78 Stephen E. Ambrose, D-Day (New York: Touchstone, 1994), 394-395; Kershaw, Blood and Champagne, 129; John G. Morris, Get the Picture, 6-7.

79 Brandt, "I Cover the Battlefront," 86.

${ }^{80}$ For the lab accident, see John G. Morris, "The Magnificent Eleven: The D-Day Photographs of Robert Capa," Skylighters, http://www.skylighters.org/photos/robertcapa.html (accessed June 23, 2016); for "immense excitement," see "Beachheads of Normandy: The Fateful Battle for Europe Is Joined by Sea and Air," Life, June 19, 1944, 27; for Capa's nervousness, see Capa, Slightly out of Focus, 148. Hans Wild, a member of Morris's darkroom staff and one of the only people to ever see the exposed film, called the ruined photographs "superb" (Kershaw, Blood and Champagne, 128-129).

${ }^{81}$ Elmer Lower to Gilberta Lower, June 11, 1944, Lower family archive. Ed Kennedy called Haynes "One of the country's best news photographers" (Kennedy and Cochran, Ed Kennedy's War, 91), while Lower said Haynes reportedly felt that "life is really just histrionics and he [was] just playing a part" (see Elmer Lower to Gilberta Lower, May 15, 1944, Lower family archive.

82 Elmer Lower to Gilberta Lower, June 11, 1944, Lower family archive.

83 Brandt, "I Cover the Battlefront," 85 
These interactions that occurred in the wake of D-Day exemplified a secondary assumption of matching theory: that serendipity can motivate match-ing in addition to goals and resources. ${ }^{84}$ The results of both the serendipitous and strategic work between these inter organizational networks produced mutually beneficial results - the editors had visceral action images to distribute for headlines across the world, which earned the photographers praise and notoriety. ${ }^{85}$ These results became a catalyst in solidifying alliances that would become the impetus for producing profoundly impactful images of the war, as seen in the months and years that followed.

Following the invasion of Normandy, many of the photographers and correspondents, including Capa, continued to report the Allied campaign as it liberated French towns along the road to Paris. But they temporarily lost the support of Lower, whom the OWI transferred to the United States in July to work for their Overseas News and Features Bureau in New York. The move was apparently a temporary assignment while the OWI considered sending Lower to the Pacific theater. 86

Before that could happen, though, Wilson Hicks, Life's photographic editor, hired Lower to be the Paris picture editor and bureau manager for Life magazine. 87 This career move put Lower's life directly on course to once again align with Capa's, because Hicks had also given Capa an official staff position with the magazine. 88 Both appointments were part of Hicks's efforts to significantly expand Life's photographic staff and development of the magazine's iconic photo essay format. ${ }^{89}$ In addition to representing the war for the armchair participants around the world, Lower and Capa now had a very intimate shared goal of doing so for Life, thus drawing their mutualistic relationship even closer, strengthening their alliance, and further exemplifying matching theory.

\section{Lower and Capa Together at Life}

\footnotetext{
${ }^{84}$ Mitsuhashi and Greve, “A Matching Theory of Alliance Formation,” 975-995; Kilduff and Tsai, Social Networks and Organizations.

85 See “Bob Capa Tells,” Hi! Jinx, October 20, 1947; Treanor, “What Did You See,” Vogue.

${ }^{86}$ Cressman, Elmer W. Lower Oral History, 79.

87 Ibid. Life was apparently impressed with Lower's handle on the French language as well as his experience abroad with the OWI where he received tutoring in the language (Cressman, Elmer W. Lower Oral History, 66). However, fellow Life editor John G. Morris felt that Lower beat him to the job because he "had the good sense to marry a French girl" (John G. Morris, "ICP Lecture Series: John G. Morris," International Center of Photography, June 24, 2014.

88 Whelan, Robert Capa, 217-218.

89 John S. Bowman, The Cambridge Dictionary of American Biography (Cambridge: Cambridge University Press, 1995).
} 
Lower was back to Europe by November, just three months after the city was liberated from Nazi occupation. When he arrived in Paris, Lower moved into a room at the Scribe, a hotel that the US Army had taken over and was operating for war correspondents and public relations officers stationed in Paris. The bar at the hotel was "a confused place" in which "disheveled correspondents rushed back from the front to file their stories." 90

At the Life office, it was Lower's job to decide which photographers to assign to a particular story, with the goal of matching "a photographer's particular gifts and aptitudes." The team he had to work with included some of the most iconic photojournalists of the war. Capa, Rodger, David Scherman, and Ralph Morse, among others, had already produced work that would perceptually exemplify the war in the minds of Americans. Together they became so adept at their jobs in the following years that managing editor Daniel Longwell praised their great work and proclaimed that magazine production in New York was never closed "without asking what Paris had done." In the nine months between the liberation of Paris and V-E Day, Lower's Paris Bureau sent in twenty-seven stories that were published in the magazine. 91

When Lower arrived in Paris, Capa was out on assignment, but Lower had already recognized that Capa was a "military genius" with a willingness to take "big chances," so one of the first assignments Lower made in Paris came in December 1944 when he sent Capa to join the Fourth Armored Division's push into Bastogne to relieve the 101st Airborne Division. ${ }^{92}$ The press had taken to calling it the Battle of the Bulge, because German pressure on the American defensive line, as depicted on maps, resembled a bulge. Capa was hesitant to accept the assignment. German soldiers had been sneaking into American camps disguised in American uniforms and shooting American soldiers. Because he had a heavy Hungarian accent, Capa was "scared to death" that he would be mistaken for German and be shot on sight. Ultimately, though, "he was willing to take it 'cause Capa was a guy who took long chances."'93

Sure enough, his accent raised suspicions and caused delays on his way to the assignment, when he was stopped by MPs "every few miles" and even arrested numerous times while they verified his identity and credentials. To further validate his preliminary fears, after joining the division as

90 "Paris 1945: Life's Artists Show How the Freed City Fared," Life, July 16, 1945, 51. Lower would come to describe the Scribe as "an inbred society where almost everyone is an expert in his own opinion" (Elmer Lower to Gilberta Lower, March 4, 1945).

${ }^{91}$ For "a photographer's particular gifts," see Wilson Hicks, Words and Pictures (New York: Arno Press, 1973), 55; for "without asking," and the bureau's twenty-seven stories, see Cressman, Elmer W. Lower Oral History, 83.

92 For Capa's assignment, see Morris, Get the Picture, 92. For "military genius," see Elmer Lower to Gilberta Lower, January 1, 1945, Lower family archive; for "big chances," see Elmer Lower to Dale Cressman, August 15, 2002; Cressman, Elmer W. Lower Oral History, 84; Capa, Slightly out of Focus, 208; see "Allies Squeeze the German Bulge," Life, January 15, 1945, 15; Kershaw, Blood and Champagne, 151.

93 Cressman, Elmer W. Lower Oral History, 84. 
the only photographer, he stopped alongside a frozen, snowy field to take pictures of a battalion of advancing infantry, was mistaken fora German soldier, and was shot at before he intuitively chose to "surrender" so the soldiers could get close enough to identify him. ${ }^{94}$

Despite these setbacks, Capa continued to accompany the tanks for a week as they fought their way to Bastogne. Life reported that "Capa walked among battling tanks so intent on his work that Time and Life Correspondent Will Lang said he looked 'incongruous, a puny ringmaster in a herd of trumpeting (and oblivious) elephants." 95

Finally, on the day after Christmas 1945, Capa, Abrams, and the entire Armored Division drove their tanks into Bastogne with a mighty force that broke up the German siege. Capa had the shots - twenty-seven rolls of 35-millimeter film-despite the brutally cold weather that made it impossible to "keep [his] gloved hand on the shutter for longer than a split second." 96 Perhaps the weather was to blame, or perhaps it was simply that Capa did not feel comfortable writing in English, but when Capa returned to Paris, he had not written captions for any of the photos. ${ }^{97}$ Without captions to accompany his rolls, Capa's work in Bastogne would have been delayed or rejected by the censors, and it may have never made it to publication..$^{98}$

Lower reached out to his contacts at the Paris OWI darkroom to develop the film and make contact prints. Once that task was done, Lower and Capa sat at a table in the Scribe bar to meticulously reconstruct the events and hammer out the captions. ${ }^{99}$ Together the pair created what Lower thought was a "beautiful layout of pictures. . . an epic."100 The photos made it past censors and got to New York in time for Life's deadline. The magazine used nine of Capa's photos, along with Lower's accompanying captions, for a five-page feature the following month. 101

Life editors were so pleased with the coverage of Bastogne that they sent their compliments in the spring of 1945 and gave Capa his choice of armies to accompany on the final push for Berlin.

94 Capa, Slightly out of Focus, 207,209. In addition to his heavy European accent, the Americans may have been confused by the three German cameras Capa was wearing around his neck or the fur-lined German army overcoat he had found and was indignantly wearing. For more on the latter, see Andy Rooney, My War (New York: Public Affairs, 2008), 247-248

95 “Life's Pictures," Life, January 15, 1945, 13. See also “Allies Squeeze," Life.

96 For twenty-seven rolls, see Elmer Lower to Gilberta Lower, January 1, 1945, Lower family archive. For "keep [his] gloved hand," see Capa, Slightly out of Focus, 208.

${ }^{97}$ Elmer Lower to Gilberta Lower, January 1, 1945, Lower family archive.

98 Cressman, Elmer W. Lower Oral History, 85.

99 Ibid. Pete Urban with the OWI spent all night developing the film, for which Lower paid him one hundred dollars (see Elmer Lower to Gilberta Lower, January 1, 1945, Lower family archive.

100 Elmer Lower to Gilberta Lower, January 1, 1945, Lower family archive.

101 “Allies Squeeze," Life, 15-19. 
Lower had a different idea. He had information on a fifth army that was being prepared-the 17th Airborne Division - and had already negotiated with the pool for Capa to be included as the lone photographer on the mission - if he was willing to jump with the paratroopers. ${ }^{102}$ Never one to back down from the chance to capture the action at the front, Capa accepted the mission.

While waiting for the assignment, Lower tried to keep Capa busy with less intense stories. In February 1945, a call came from Life to help nurse-recruiting drives in the United States by doing a "day in the life of a frontline army nurse."103 Even though the assignment was probably better suited for Ralph Morse, an "ebullient" chronicler of the human condition, Lower gave it to Capa, and the two traveled together to northern France. ${ }^{104}$

After they photographed the nurses, Lower took advantage of their location and took Capa along to visit his wife's family in nearby Vaudeville while awaiting their return train. Although Capa was ill, he "had a swell time" at dinner where he quickly built rapport with Gilberta's father by sharing stories and racy remarks. ${ }^{105}$ By taking Capa to visit his father-in-law, Lower shared an important part of his personal life with Capa. In doing so, the two had merged their professional and personal relationships, further demonstrating the depth of the mutualistic bond that had developed between them.

Shortly after their trip to the front, Capa took leave to rejuvenate in the French Alps. When the time finally came, in March, for Capa to join the 17th Airborne Division, Lower sent a telegram for Capa to report for duty. Capa joined the paratroopers and parachuted, with some amount of trepidation, behind enemy lines to capture General Montgomery's crossing of the Rhine. Back in form, Capa photographed the parachuting soldiers and the ensuing battle for more than eight hours, and when the day ended and he could not secure transport back to Paris, Capa slept the night wrapped in a parachute, before hitchhiking back to Paris. ${ }^{106}$ Capa biographer Whelan reported that "he had gotten a great story and wanted to send it through as quickly as possible." 107 When he finally showed up in Paris "unshaven and haggard," with fourteen rolls of 35-millimeter film that once again included no captions, Lower and his darkroom men took over, once again working through the night to develop the images so Capa and Lower could work

102 Capa, Slightly out of Focus, 219.

103 In January, "Capa got some cute pictures... of a Paris snow fight" before taking the frontline assignment (Elmer Lower to Gilberta Lower, January 29, 1945, Lower family archive).

104 Elmer Lower to Gilberta Lower, February 7, 1945, Lower family archive.

105 Ibid.

106 In John Hersey's account, Capa ordered whiskey to the division's classified base to soothe his nerves before the mission (see John Hersey, "The Man Who Invented Himself," 47: The Magazine of the Year, September 1947, 75-76). Lower reported that Capa "hitchhiked about nine different rides, got a plane for a certain distance, then made the last lap by train" (Elmer Lower to Gilberta Lower, March 28, 1945, Lower family archive).

107 Whelan, Robert Capa, 235. 
together to write the captions. The following morning, Lower got censor approval and delivered the photos for transport to New York. Although they had not expected to get Capa's work in time for that week's transport, when they saw it, they understood Capa's urgency. Lower called the work "the best job of [Capa's] career."108 The team was right-Life gave the story eleven pages. 109

Capa's final assignment of the war was the liberation of Leipzig on April 18, 1945. The war was practically over - the Russians were already in Berlin, and Capa was hoping to capture the perfect image of the waning war. ${ }^{110}$ As the troops swept through, Capa took a series of photos of a young American sergeant manning a machine gun on a balcony. Just as Capa photographed him, the sergeant was shot by a sniper. As Capa watched, the soldier slumped to the ground, and he died as a pool of blood spread beneath him. Capa's chronicle of these last moments of life and the war became what Capa remembered most of the entire war and became a poignant capstone of the war for many people when they were printed in Life the following month. ${ }^{111}$ Later, Capa wrote, "The last day, some of the best ones die."112

To Capa, the war was all but over. When he returned to Paris, he took leave to London and left Lower in Paris with only Morse to take assignments. Less than two weeks later, on May 5, an assignment came from the United States still photo pool. Although Lower usually tried to avoid giving his men the often mundane pool assignments, it was his team's turn, and after dragging his feet, Lower handed the unspecified orders to Morse, since no one else was in Paris at the time. ${ }^{113}$ The undesirable, supposedly mundane assignment turned out to be the German Army's surrender in Reims, France, on May 7. When Lower realized how close he had come to not sending a photographer, he knew he "nearly screwed [himself] there."114 Even though Capa was

108 Elmer Lower to Gilberta Lower, March 28, 1945.

109 “Last Round," Life, April 9, 1945, 27-37.

110 Lower said that Capa had "gone back to score another ace before the war ends" (Elmer Lower to Gilberta Lower, April 2, 1945, Lower family archive.

111 Capa related how impactful the events were in "Bob Capa Tells," Hi! Jinx, October 20, 1947. The images and story were published in "End of War," Life, May 14, 1945.

112 Capa, Slightly out of Focus, 236. Coincidentally, Pyle was shot and killed the same day on the Pacific island of Ie Shima (see Kershaw, Blood and Champagne, 156).

113 Cressman, Elmer W. Lower Oral History, 86. This was no slight to Morse, whom Lower called "a hard conscientious worker" (Elmer Lower to Gilberta Lower, April 16, 1945, Lower family archive) who "excites my admiration at the moment" (Elmer Lower to Gilberta Lower, May 2, 1945, Lower family archive).

114 Cressman, Elmer W. Lower Oral History, 86. 
not in Paris and may have quite possibly shrugged off the assignment had he been there, he was "furious" he had not gotten the assignment he had been waiting for. ${ }^{115}$

In the following months, Lower and Capa continued to work together on assignments that further solidified their relationship, but the war in Europe was over, and the war in the Pacific was waning. During the fall of 1945, "the correspondents changed from war correspondents to foreign correspondents," and the Army prepared to give the Scribe back to the French. It was the last call. Capa and Lower's work was done. ${ }^{116}$

\section{Conclusions}

In producing some of the most compelling photojournalism of World War II, Robert Capa and Elmer Lower had created a mutualistic relationship. Capa provided stunning photos, while Lower supplied logistical and editorial support that gave Capa wider exposure. Lower described a system "whereby [Capa] dashes back here and we whip his stuff out fast. Others ship to London which is alright for them. But Capa doesn't write very lucid captions and needs the desk help more than some of the others." 117 Together they created a visual narrative of World War II that included indelible images fromNorth Africa, Italy, Normandy, the Battle of the Bulge, and Leipzig, among others. The tenets of matching theory and alliance formation had been solidified, and the images that their partnership were able to produce as a result of their alliance transcended the moment of their shared lives to inform history.

Pyle biographer Tobin describes such alliances as "a sacred circle of comradeship. . . that could be kindled only in war's ashes."118 The relation-ship and mutual respect between the two extended beyond the war. In 1951, Capa approached Lower, rather than others, such as long-time friend Morris, to preside over his photo agency, Magnum. Lower declined so he could accept a job with CBS that would set the foundation for his pioneering work in television news. ${ }^{119}$ Capa ran the agency himself until his untimely death in 1954, when he stepped on a landmine while

115 Whelan, Robert Capa, 237. Capa actually offered an alternate version of the story assignment in which he did shrug off the assignment. According to the story, told to John Hersey in "The Man Who Invented Himself," Capa was personally approached by a public relations officer to take "a little job" while playing poker at SHAEF headquarters but could not be bothered by something so trivial, so the officer gave the assignment to someone else, and Capa missed the Armistice (Hersey, "The Man Who Invented Himself," 76). Lower later told Capa biographer Richard Whelan that the story was a fabrication (see Whelan, Robert Capa, 237).

116 Elmer Lower to Gilberta Lower, September 11, 1945, August 21, 1945, October 2, 1945, Lower family archive.

117 Elmer Lower to Gilberta Lower, April 2, 1945, Lower family archive.

118 Tobin, Ernie Pyle’s War, 138, 147.

119 Whelan interview of Lower, June 14, 1982, 4; For more research detailing Lower's influence on both news and sports television history, see Cressman, "Fighting for Access"; Dale L. Cressman and Lisa Swenson, "The Pigskin and the Picture Tube: The National Football League's First Full Season on the CBS Television Network," Journal of Broadcasting \& Electronic Media 51, no. 3 (2007): 479-497. 
reporting on the First Indochina War, but given that Magnum was founded to protect the rights of photographers from the magazines and the editors, Capa's request said even more about how much he admired and trusted Lower.

World War II correspondent Don Whitehead insisted that "twenty-four hours in the life of a war correspondent is not particularly important to any-one but the correspondent himself." However, Lower and Capa's mutualistic relationship, similar to the relationships of other photographers and photo editors of the war, has produced photojournalism that continues to permeate our lives today. When we think of the aerial photos, the mountainous terrain, the washed-out beaches, the frosty battlefields, the skies filled with paratroopers, the concentration camps, and the last fallen soldier - all of which exemplified the courage, fear, heroism, violence, humanity, and atrocities of World War II - it is directly attributable to the skilled photojournalists and photo editors who captured a monumental part of history, presented it to the home-front audience, and preserved it for generations to come. Naggar argued that there are many people today "whose sense of self was shaped by those images," and Moeller took it one step further in arguing that our attitudes toward war are influenced by "visual knowledge gained from photography."120 While World War II may have been beyond societal reach for most people of the time, as Lippmann argued, and it is certainly beyond historical reach for the majority of people living today, the mutualistic relationships between photojournalists and photo editors during the war ensured that it would never be beyond our awareness or visual reach.

120 For "twenty-four hours in the life," see Whitehead, Beachhead Don, 96. Ironically, this article was written from the Anzio beachhead, during a battle that would captivate the attention of newspapers and readers throughout the world for months. For "whose sense of self," see Naggar, George Rodger, 142; for "visual knowledge gained," see Moeller, Shooting War, 7. 